\section{Scaled-Down Nuclease P1 for Scaled-Up DNA Digestion}

\author{
BioTechniques 34:908-909 (May 2003)
}

Motivated by an interest in detecting DNA adducts in their nucleotide form by mass spectrometry (1), we sought efficient, low-cost conditions for enzymatic digestion of a relatively large amount of DNA ( $\geq 1 \mathrm{mg}$ ). Of the enzymes available for such digestion, nuclease P1, which forms deoxynucleoside-5'-monophosphates, seemed to be a good initial choice because it is widely used for digesting DNA, very stable, and relatively low in cost.

However, considering our goal of detecting DNA adducts, a study of the literature revealed three uncertainties concerning the use of this enzyme for hydrolyzing a large amount of DNA. First, some workers denature the DNA first by heating $\left(95^{\circ} \mathrm{C}-100^{\circ} \mathrm{C}\right)$ to accelerate the subsequent enzymatic digestion $(2,3)$. Since this could both create and modify some DNA adducts, it was a condition that we wanted to avoid. Second, many variations have been reported in digestion conditions, including the amount of the enzyme, which has ranged up to a cost equivalent to about \$30/mg DNA. Third, few studies have assessed the degree of digestion.

Although the prior literature contains many methods for digesting DNA with nuclease P1, the one by McGall et al. (4) seemed to provide a good starting point because they digested unheated DNA at a relatively high concentration of about $0.2 \mathrm{mg} / \mathrm{mL}$. To fully optimize nucleotide yield, we varied all of their digestion conditions. Hoechst dye binding was used to quantify the DNA before digestion, and HPLC-UV was used to quantify the nucleotides afterwards.

Our recommended method is as follows: $1 \mathrm{mg}$ DNA in $1.05 \mathrm{~mL}$ water in a plastic tube (Brinkman, Westbury, NY, USA) is treated with $200 \mu \mathrm{L} 5 \mathrm{mM}$ $\mathrm{ZnCl}_{2}, 300 \mu \mathrm{L} 50 \mathrm{mM}$ sodium acetate, $\mathrm{pH} 5.5$, and $2 \mathrm{U}(2 \mu \mathrm{L})$ nuclease P1 (Roche Applied Science, Indianapolis, IN, USA, unless indicated otherwise), giving a total volume of $1.55 \mathrm{~mL}$ with $1.3 \mathrm{U} / \mathrm{mL}$ nuclease $\mathrm{P} 1,0.65 \mathrm{mM}$
$\mathrm{ZnCl}_{2}$, and $9.7 \mathrm{mM}$ sodium acetate. The tube is capped and kept for $2 \mathrm{~h}$ at $37^{\circ} \mathrm{C}-38^{\circ} \mathrm{C}$ before centrifugal ultrafiltration $\left(2 \mathrm{~mL}\right.$ Centricon $\mathrm{YM}-10^{\mathrm{TM}}$; Fisher Scientific, Pittsburgh, PA, USA) and injection of $20 \mu \mathrm{L}$ into an HPLC column to assess the yield of nucleotides. Figure 1 shows an HPLC chromatogram from such a digestion. According to our measurements, $88 \%$ of the DNA is hydrolyzed to nucleotides, but the true degree of hydrolysis may be essentially $100 \%$ considering the limited accuracy, especially of the dye-binding assay. The digestion appeared to be complete (by HPLC) after $1 \mathrm{~h}$, but only about $70 \%$ hydrolysis took place after $0.5 \mathrm{~h}$.

Relative to the conditions reported by McGall et al. (4), mainly we increased the concentration of DNA by 3.2-fold and reduced the relative amount of enzyme by 16 times, so about $\$ 0.43$ of enzyme is used per milligram of DNA. While doubling the latter amount of enzyme had no effect (tested at $\mathrm{pH} 6.0$ with a 2-h digestion time in succinate buffer), half the amount of enzyme gave late-eluting peaks (at about $20 \mathrm{~min}$ ) in the HPLC chromatogram, apparently from incomplete digestion. Our final amount of enzyme $(2 \mathrm{U} / \mathrm{mg}$ DNA) is 2 times lower than the lowest value reported before (5).
Most of the optimization experiments were done on 30- $\mu$ g amounts of DNA. Curiously, when a relatively high dose of nuclease P1 was tested in such an experiment, deoxyadenosine (dA) formed as a side product, giving an extra peak in the HPLC chromatogram, as shown in Figure 2A. We identified this peak as dA by (i) measuring its UV spectrum, (ii) determining that it coeluted with added dA, and (iii) observing that adenosine deaminase converted this product to deoxyinosine. Note as well that the peak for dAMP is relatively larger (Figure 2B) when less nuclease P1 is added. No dA formed when DNA was omitted from the experiment, and the amount of dA did not increase with an extended incubation time. When authentic dA- $5^{\prime}$-monophosphate was incubated with nuclease P1, the peak did not form. Nuclease P1 from Sigma-Aldrich (St. Louis, MO, USA) gave the same result. We did not characterize this event in more detail. It may be relevant that for both DNA (6) and dideoxynucleotides (7), the phosphodiester bond $3^{\prime}$ to an adenine nucleotide is a preferred site of hydrolysis by this enzyme.

The 3'-phosphodiester linkage of some nucleobase DNA adducts resists digestion by nuclease P1, yielding dinucleotides (8) or trinucleotides (9), but this may be acceptable for our purposes.

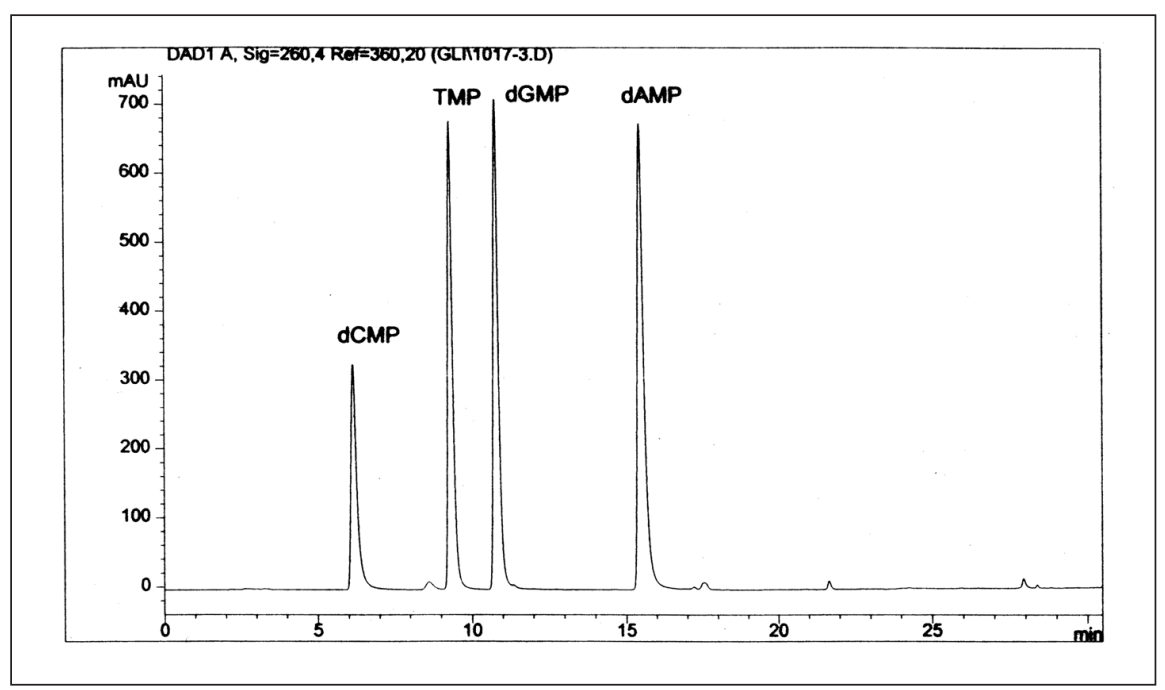

Figure 1. HPLC chromatogram of deoxynucleotides derived from digesting $1 \mathrm{mg}$ calf thymus DNA (Sigma-Aldrich) with nuclease P1. See text for digestion conditions. Injection: $20 \mu \mathrm{L}$ ultrafiltrate. Column: Aquasil C18, $250 \times 4.6$ mm, $5 \mu \mathrm{m}$ packing (Thermo Hypersil-Keystone, Bellefonte, PA, USA). Mobile-phase components: A is $20 \mathrm{mM}$ ammonium acetate, $\mathrm{pH} 5.5$; $\mathrm{B}$ is methanol. Gradient: $0 \%-10 \% \mathrm{~B}$ from $0-10 \mathrm{~min}$, then to $20 \%$ at $15 \mathrm{~min}$, and to $90 \%$ at $30 \mathrm{~min}$, followed by a drop to $0 \% \mathrm{~B}$ and a $10-\mathrm{min}$ equilibration before the next injection. 


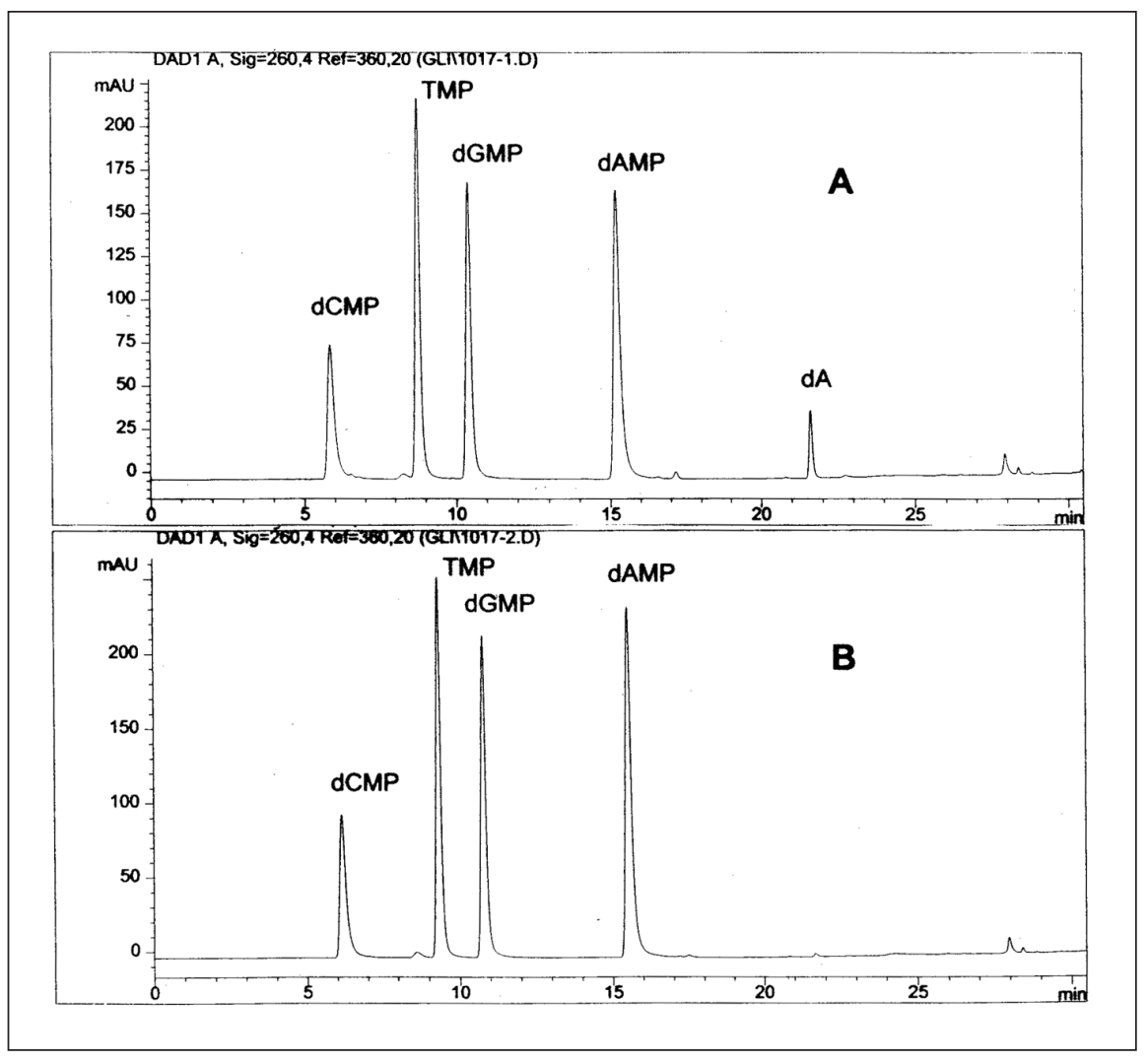

Figure 2. HPLC chromatograms obtained in the same way as that of Figure 1, except $30 \mu \mathrm{g}$ DNA were digested with 7.5 (A) and $0.06 \mathrm{U}(\mathrm{B})$ nuclease $\mathrm{P1}$ in a total volume of $120 \mu \mathrm{L}$.

Other enzymes(s) will need to be added in methods where this complicates the analysis. For example, snake venom phosphodiesterase has been used for this purpose $(2,8)$. Others have reported that the addition of deoxyribonuclease I and phosphodiesterases I and II improved the completeness of digestion and lowered variability in the detection of the DNA adduct 8-oxo-G as a nucleoside, relative to digestion by just nuclease P1 (10). On the other hand, for some heterocyclic amine DNA adducts, nuclease P1 was used, after the adducts were labeled with a kinase, to overcome incomplete hydrolysis to mononucleotides by micrococcal nuclease and spleen phosphodiesterase $(11,12)$.

Thus, we have learned that a relatively large amount of DNA $(1 \mathrm{mg})$ in a moderate volume $(1.55 \mathrm{~mL})$ can be hydrolyzed to give a high yield of nucleotides with a relatively small amount of nuclease $\mathrm{P} 1$ in terms of enzyme cost. The digestion reaches an end point in less than $2 \mathrm{~h}$ at $37^{\circ} \mathrm{C}$, which is both convenient and mild for studies of DNA adducts. Only digestion with an excessive amount of the nuclease $\mathrm{P} 1$ reagent formed some $\mathrm{dA}$ as a side product.

\section{REFERENCES}

1.Lan, Z-H., P. Wang, and R.W. Giese. 1999. Matrix-assisted laser desorption/ionization mass spectrometry of deoxynucleotides labeled with an IMI Dye. Rapid Commun. Mass Spectrom. 13:1454-1457.

2.Crain, P.F. 1990. Preparation and enzymatic hydrolysis of DNA and RNA for ,ass spectrometry. Methods Enzymol. 193:782-790.

3.Kaneko, T., K. Katoh, M. Fujimoto, M. Kumagai, J. Tamaoka, and Y. Katayama-Fujimura. 1986. Determination of the nucleotide composition of a deoxyribonucleic acid by high-performance liquid chromatography of its enzymatic hydrolysate: a review. J. Microbiol. Methods 4:229-240.

4.McGall, G.H., L.R. Rabow, G.W. Ashley, S.H. Wu, J.W. Kozarich, and J. Stubbe. 1992. New insight into the mechanism of base propenal formation during bleomycin-mediated DNA degradation. J. Am. Chem. Soc. 114:4958-4967.

5.Itoh, S., T. Hirai, Y. Totsuka, H. Takagi, Y. Tashiro, K. Wada, K. Wakabayashi, S. Shibutani, and I. Yoshizawa. 1998. Identification of estrogen-modified nucleosides from calf thymus DNA reacted with 6-hydroxyestrogen 6-sulfates. Chem. Res. Toxicol. 11:1312-1318.

6.Fujimoto, M., K. Fujiyama, A. Kuninaka, and H. Yoshino. 1974. Mode of action of Nuclease $\mathrm{P}_{1}$ on nucleic acids and its specificity for synthetic phosphodiesters. Agr. Biol. Chem. 38:2141-2147.

7.Box, H.C., E.E. Budzinski, M.S. Evans, J.B. French, and A.E. Maccubbin. 1993. The differential lysis of phosphoester bonds by nuclease P1. Biochim. Biophys. Acta 1161:291-294.

8.Randerath, K., E. Randerath, T.F. Danna, K.L. van Golen, and K.L. Putman. 1989. A new sensitive 32P-postlabeling assay based on the specific enzymatic conversion of bulky DNA lesions to radiolabeled dinucleotides and nucleoside 5-monophosphates. Carcinogenesis 10:1231-1239.

9.Wang, Y., J-S. Taylor, and M.L. Gross. 1999. Nuclease P1 digestion combined with tandem mass spectrometry for the structure determination of DNA photoproducts. Chem. Res. Toxicol. 12:1077-1082.

10.Huang, X., J. Powell, L.A. Mooney, C. Li, and K. Frenkel. 2001. Importance of complete DNA digestion in minimizing variability of 8 oxo dG analyses. Free Rad. Biol. Med. 31:1341-1351.

11.Pfau, W., U. Brockstedt, K-D. Sohren, and H. Marquardt. 1994. ${ }^{32}$ Post-labeling analysis of DNA adducts formed by food-derived heterocyclic amines: evidence for incomplete hydrolysis and a procedure for adduct pattern simplification. Carcinogenesis 15:877-882.

12.Wohlin, P., M. Zeisig, J.-A. Gustafsson, and L. Moller. 1996. ${ }^{32}$ P-HPLC analysis of DNA adducts formed in vitro and in vivo by 2 amino-1-methyl-6-phenylimidazo[4,5-b]pyridine and 2-amino-3,4,8-trimethyl-3H-imidazo[4,5,f]quinoxaline, utilizing an improved adduct enrichment procedure. Chem. Res. Toxicol. 9:1050-1056.

We thank Peter Dedon and Christiane Struve for bringing the McGall procedure to our attention. This work was supported by contract no. 340811 E3119 from the Massachusetts Department of Public Health, NIEHS grant no. ES10539, National Institutes of Health grant no. CA71993, and National Cancer Institute grant no. CA84641. Contribution No. 821 from the Barnett Institute. Address correspondence to $\mathrm{Dr}$. Roger Giese, Northeastern University, Pharmaceutical Sciences MS 0122 MU, 360 Huntington Ave., Boston, MA 02115, USA.e-mail:r.giese@neu.edu

Received 16 January 2003; accepted 11 February 2003.

\section{Guodong Li, Olga Shimelis, Xiaojuan Zhou, and Roger \\ W. Giese}

Northeastern University

Boston, MA, USA 